\title{
Improvement of Low Fat Kashkaval Cheese Quality by Using Transglutaminase: a-The Impact on Chemical Composition and Sensory Properties
}

\author{
Amira M. El-Kholy ${ }^{\varpi}$ A. M. Abou El-Nour; R. A. M. Khalil; M. S. El-Safty and Safaa M. Mokbel \\ Dairy Department, Faculty of Agriculture, Suez Canal University, Ismailia 41522, Egypt
}

Received: $18 / 11 / 2020$

\begin{abstract}
The objective of the current study was to investigate the impact of using Transglutaminase at different dosage on some Physico-Chemical, and sensory attributes of obtained low fat kashkaval cheese and to monitor the changes of cheese quality during the ripening period. Results revealed that, by adding TGase, low fat cheese yield increased. There is also an increase in moisture, fat based on dry matter, total nitrogen, Salt on moisture content as compared to low fat control cheese. These increments were proportional with TGase level added. While, there is a significant $(\mathrm{p} \leq 0.05)$ decrease in acidity \%. Data showed that using Transglutaminase increased WSN \%, WSN/TN \%, FAA and TVFA compared with full and low fat control cheese. The addition of Transglutaminase to low-fat kashkaval cheese highly $(\mathrm{P} \leq 0.05)$ improved the flavour, the body \& texture, appearance and overall acceptability. A linear relationship was found between the concentration of TGase used and the improvement of cheese sensory attributes. Low fat Kashkaval cheese can be successfully made from milk treated with $0.7 \mathrm{~g}$ TGase/L in order to obtain cheese of improved flavour, acceptable texture and good body.
\end{abstract}

Keywords: Low fat cheese, Kashkaval cheese, Sensory attributes, Transglutaminase

\section{INTRODUCTION}

Kashkaval cheese is one of the most popular semihard cheeses in many Mediterranean countries. Kashkaval cheese formerly manufactured from sheep's milk. At present, it is manufacture from cows, goats, buffalo's or from a mixture of these milks, which may be raw or pasteurized. Kashkaval name is derives from the Italian cheese "Caciocavallo". It is particularly popular in Eastern Europe and Mediterranean region. This cheese is also found in Hungary, Croatia, and Turkey. The Romanians call this cheese cascaval, the Greeks kasseri while the Turkish prefer to interpret it as Ksara. Kashkaval belongs to the pasta filata cheeses. This means that the curd is given a hot bath during the production process (Alichanidis and Polychroniadou, 2008).

In recent years, increased consumer interest on healthy lifestyle has led to an increased demand for low fat foods in particular low fat cheese. Fat acts as a plasticizer and affects cheese texture. Reduced and low fat cheeses are lacking in the distinctive cheese flavor and texture is not comparable to full fat cheeses (Koca and Metin, 2004; Ahmed et al., 2015).

Transglutaminase (TGase) is one of the enzymes used recently to enhance the texture of cheese that is low in fat. By cross-linking the amino acids TGase forming bonds between several proteins reduces the protein bond between glutamic and lysine. The rate of TGase cross-linking depends on the macromolecular structure of protein involved. Many food proteins, particularly casein, which is the principle protein in milk, are good substrates for TGases. The cross-links introduced by this enzyme alter the structure of the protein and enhance its functional properties, such as texture, viscosity and capacity to retain water, without decomposing the nutritional content of the lysine residue (Seguro et al., 1996). TGase treatment can reduce cheese lesses, improve water retention in reduced fat cheeses and in turn increasing cheese yield and improving cheese quality.
Therefore, the aim of this study was to investigate the impact of using transglutaminase at different dosage on some Pyhsico-Chemical, and sensory properties of obtained low fat kashkaval cheese and to monitor the changes of cheese quality during the ripening period.

\section{Materials:}

\section{MATERIALS AND METHODS}

Fresh Cow's and buffalo's milk were obtained from the herd of Faculty of Agriculture, Suez Canal University, Ismailia governorate. Direct Vat Starter (DVS) yoghurt culture containing Streptococcus thermophiles and Lactobacillus delbrueckii ssp. bulgaricus and Rennet powder, CHY-MAX were obtained from Chr-Hansen's laboratories, Denmark. Commercial salt was obtained from the local market. Calcium chloride was obtained from El-Naser pharmaceutical and chemical company, Cairo governorate, Egypt. Transglutaminase was obtained from Ajinomoto Europe Sales GmbH, Hamburg, Germany.

\section{Experimental procedure:}

Five treatments were carried out. Treatment 1 (T1) was made from mixture of buffalo's and cow's milk (1:1) standardized to $3.25 \%$ fat to serve as full fat cheese control. The other four treatments were made from mixture of buffalo's and cow's milk (1:1) standardized to $1 \%$ fat, milk then divided to four portions: the first portion treatment 2 (T2) was regarded as low fat Kashkaval cheese control. Treatment 3 (T3), treatment 4 (T4) and treatment 5 (T5) were made by adding Transglutaminase (TGase) at the rate of $0.3,0.5$ and $0.7 \mathrm{~g} /$ Liter respectively. Kashkaval cheese was manufactured according to Simov and Ivanov (2005) by the process described in Fig. (1). The levels, incubation and the inactivation temperature of TGase were used according to Ajinomoto applications data. The resultant cheese was stored for 45 days at $10 \mathrm{C}$ and $80 \%$ relative 
humidity. The whole experiment was repeated in triplicate and each analysis in duplicate and average results were tabulated. The chemical composition of standardized milk used to make full and low fat Kashkaval cheese is shown in Table (1).

Table (1): Chemical composition (\%) of standardized milk used to make low fat Kashkaval cheese (Mean value of three replicates)

\begin{tabular}{lcccc}
\hline Type of milk & TS\% & Fat\% & Casein & C/ F \\
\hline Buffalo's and cow's milk (1:1) & 12 & 3.25 & 2.6 & 0.8 \\
Low fat buffalo's and cow's milk (1:1) & 9.5 & 1 & 2.6 & 2.6 \\
\hline
\end{tabular}

Cheese samples were analyzed when fresh, 15, 30 and 45 days for the chemical analysis and sensory evaluation.

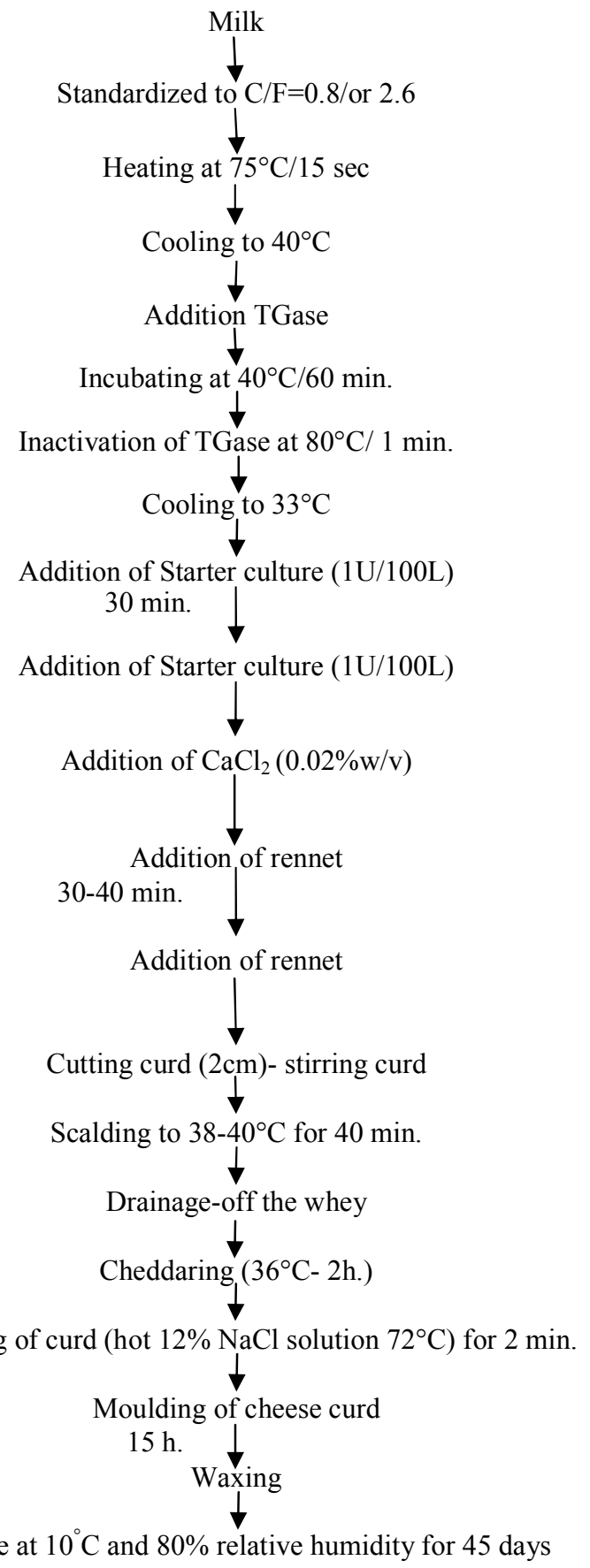

Fig (1): Flow sheet of the production of Kashkaval cheese treated with TGase 


\section{Methods of analysis:}

Analysis of cheese milk (Total solids; Fat; and Casein content) was carried out according to the methods described in AOAC (2007). Cheese samples were analyzed chemically when fresh and after 15, 30 and 45 days of storage. Moisture content, water soluble nitrogen (WSN) and total nitrogen content (TN) were measured by Kjeldahl method using semi-micro Kjeldahl according to the methods described by AOAC (2007). Acidity was determined by the titration method according to Vujicic et al. (1996). $\mathrm{pH}$ value was measured by using (Jenway digital pH meter, Jenway Limited, England). Salt content was determined according to Volhard method and fat content by Gerber butyrometer described by Ling (1963). The yield of fresh cheese was recorded as $\mathrm{kg}$ of cheese $/ 100 \mathrm{~kg}$ of cheese milk as the formula given by Fox et al. (2000). Free amino acids value was estimating (expressed as Absorbance at $507 \mathrm{~nm} / 100 \mu \mathrm{l} \mathrm{WSN}$ ) using cadmiumninhydrin method as described by Folkertsma and Fox (1990). Total volatile fatty acids contents (TVFA) were estimated by the distillation method according to Kosikowski (1982), results were expressed as ml N/10 $\mathrm{NaOH}$ per $100 \mathrm{~g}$ cheese.

\section{Sensory evaluation:}

The sensory evaluation of cheese samples was evaluated according to the method of Pappas et al. (1996) when fresh and after 15, 30 and 45 days of storage with maximum score points for flavour (50 points), body and texture (40 points) and appearance and colour (10 points). The sensory evaluation was carried out by 15 members of Dairy department, Faculty of Agriculture, Suez Canal University.

\section{Statistical analysis:}

All measurements were done in triplicate and analysis of variance with two factorial (treatments and storage period) were conducted by the procedure of
General Linear Model (GLM) using CoStat (1998) under windows software version 6.311 and least significant difference (LSD) test were employed to determine significant difference at $\mathrm{p}<0.05$.

\section{RESULTS AND DISCUSSION}

\section{Cheese yield and chemical composition of cheese whey:}

Full fat cheese (T1) exhibit the highest yield $(\mathrm{P} \leq 0.05)$ among all treatments that is because the milk fat is one of the major components in which it is trapped in the protein matrix during cheese making Table (2). While, yield of low fat Kashkaval cheese decreased significantly $(\mathrm{P} \leq 0.05)$ compared to control full fat cheese. This due to fat in cheese can be replaced by moisture, but the increased moisture was not enough to fill the volume left by the reduction in fat (Ya-nan Hu et al., 2013). Cheese made from milk treated with $0.7 \mathrm{~g} / \mathrm{L}$ TGase (T5) had higher $(\mathrm{P} \leq 0.05)$ yield than control low fat Kashkaval cheese and other treatments treated with TGase. Han and Spradin (2000) concluded that increasing yield of cheese could be due to whey protein retained in the cheese curd and reported that the proportion of whey protein product incorporated into the cheese curd increases essentially as the amount of TGase added is increased. These results in agreement with (El-Kholy, 2005; Ahmed et al., 2015; Karzan et al., 2016).

Table (2) reveals TS\%, Fat $\%$, TP\% of whey drained from cheese of different treatments as affected by TGase treated milk. The results indicated that TS, fat and protein $(\%)$ in the whey drained from full-fat treatment (T1) higher compared to all low fat treatments. As the amount of Transglutaminase increased the loss of TS, fat and protein in the whey decreased. These results in accordance with El-Kholy (2005) for low fat Tallaga cheese.

Table (2): Effect of using different percentages of Transglutaminase on cheese yield and the chemical composition of low fat Kashkaval cheese whey (Mean of three replicates)

\begin{tabular}{lcccc}
\hline \multirow{2}{*}{ Treatments } & $\begin{array}{c}\text { Cheese yield } \\
(\%)\end{array}$ & TS\% & Chemical composition of whey \\
\cline { 2 - 4 } & $12.70^{\mathrm{a}}$ & $6.70^{\mathrm{a}}$ & Fat $\%^{\mathrm{a}}$ & Protein\% \\
\hline T1 & $9.00^{\mathrm{d}}$ & $6.35^{\mathrm{b}}$ & $0.3^{\mathrm{a}}$ & $0.65^{\mathrm{a}}$ \\
T2 & $9.86^{\mathrm{c}}$ & $6.30^{\mathrm{bc}}$ & $0.2^{\mathrm{b}}$ & $0.58^{\mathrm{b}}$ \\
T3 & $10.13^{\mathrm{b}}$ & $6.26^{\mathrm{bc}}$ & $0.1^{\mathrm{c}}$ & $0.51^{\mathrm{c}}$ \\
T4 & $10.36^{\mathrm{b}}$ & $6.22^{\mathrm{c}}$ & $0.1^{\mathrm{c}}$ & $0.49^{\mathrm{d}}$ \\
T5 & $0.1^{\mathrm{c}}$ & $0.46^{\mathrm{e}}$ \\
\hline
\end{tabular}

T1: control full fat, T2: control low fat, T3: 0.3 gTGase/L, T4: 0.5 g TGase/L, T5: $0.7 \mathrm{~g}$ TGase/L

$* a, b, c, d$ and e: means with the same letters among treatments are not significantly different $(p>0.05)$

\section{Chemical composition of cheese:}

As shown in Table (3), moisture content of low fat Kashkaval cheese treatments pronouncedly $(\mathrm{p} \leq 0.05)$ higher than full-fat cheese (T1). According to Özrenk (2006), and Gauche et al. (2008), TGase-catalyzed cross-linking in casein micelles show a better waterholding capacity, meaning that more free water can be entrapped in the rennet gel network, and therefore the moisture content increases. Furthermore, the differences in moisture content between the full fat and the low fat cheese may be attributed to their protein content, i.e. a higher protein content of low fat cheese may contribute to increase water binding capacity of the cheese matrix (Romeih et al., 2002; Ahmed et al., 2015). On the other hand, the moisture content of all treatments showed a marked $(p \leq 0.05)$ decrease as storage period progressed. Similar results also observed by Abd El-Gawad et al. (2007), El-Aidie et al. (2019). According to Ya-nan Hu et al. (2013), more free water can be entrapped in the rennet gel network, and therefore the moisture content increases and this effect more pronounced for low fat cheese than full fat cheese. 
Table (3): Effect of using different percentages of Transglutaminase on the chemical composition of low fat Kashkaval cheese during storage period at $10^{\circ} \mathrm{C}$ (Mean of three replicates)

\begin{tabular}{|c|c|c|c|c|c|}
\hline \multirow{3}{*}{ Treatments } & \multicolumn{4}{|c|}{ Storage period (days) } & \multirow{3}{*}{ Mean } \\
\hline & Fresh & 15 & 30 & 45 & \\
\hline & \multicolumn{4}{|c|}{ Moisture content (\%) } & \\
\hline T1 & 43.5 & 42.11 & 41.60 & 41.13 & $42.09^{\mathrm{E}}$ \\
\hline $\mathbf{T 2}$ & 45.70 & 43.67 & 43.03 & 42.41 & $43.70^{\mathrm{D}}$ \\
\hline T3 & 46.60 & 45.10 & 44.53 & 44.00 & $45.06^{\mathrm{C}}$ \\
\hline T4 & 47.23 & 45.80 & 45.26 & 44.77 & $45.77^{\mathrm{B}}$ \\
\hline T5 & 47.85 & 46.37 & 45.85 & 45.37 & $46.36^{\mathrm{A}}$ \\
\hline Mean & $46.18^{\mathrm{a}}$ & $44.61^{b}$ & $44.05^{c}$ & $43.54^{d}$ & \\
\hline \multicolumn{6}{|c|}{${ }^{*}$ F/DM\% } \\
\hline T1 & 42.48 & 48.19 & 48.80 & 48.92 & $47.05^{\mathrm{A}}$ \\
\hline $\mathbf{T} 2$ & 15.15 & 15.48 & 15.51 & 15.74 & $15.47^{\mathrm{E}}$ \\
\hline T3 & 15.35 & 15.50 & 15.53 & 15.75 & $15.53^{\mathrm{D}}$ \\
\hline T4 & 15.92 & 15.85 & 16.04 & 16.07 & $15.97^{\mathrm{C}}$ \\
\hline T5 & 16.57 & 16.33 & 16.50 & 16.50 & $16.48^{\mathrm{B}}$ \\
\hline Mean & $21.05^{d}$ & $22.27^{\mathrm{c}}$ & $22.48^{b}$ & $22.59^{\mathrm{a}}$ & \\
\hline \multicolumn{6}{|c|}{${ }^{*}$ TN\% } \\
\hline T1 & 4.11 & 4.25 & 4.3 & 4.36 & $4.25^{\mathrm{D}}$ \\
\hline $\mathbf{T 2}$ & 6.22 & 6.36 & 6.49 & 6.53 & $6.40^{\mathrm{C}}$ \\
\hline T3 & 6.27 & 6.38 & 6.52 & 6.57 & $6.43^{\mathrm{C}}$ \\
\hline T4 & 6.29 & 6.44 & 6.56 & 6.61 & $6.47^{\mathrm{B}}$ \\
\hline T5 & 6.33 & 6.48 & 6.59 & 6.65 & $6.51^{\mathrm{A}}$ \\
\hline Mean $^{* *}$ & $5.844^{d}$ & $5.982^{c}$ & $6.092^{b}$ & $6.144^{\mathrm{a}}$ & \\
\hline \multicolumn{6}{|c|}{ "S/M\% } \\
\hline T1 & 2.85 & 3.06 & 3.20 & 3.33 & $3.11^{\mathrm{C}}$ \\
\hline $\mathbf{T 2}$ & 2.80 & 3.07 & 3.23 & 3.40 & $3.13^{\mathrm{BC}}$ \\
\hline T3 & 2.88 & 3.08 & 3.21 & 3.36 & $3.13^{\mathrm{BC}}$ \\
\hline $\mathbf{T 4}$ & 2.90 & 3.10 & 3.25 & 3.37 & $3.16^{\mathrm{B}}$ \\
\hline T5 & 2.95 & 3.17 & 3.29 & 3.44 & $3.21^{\mathrm{A}}$ \\
\hline Mean $^{* * *}$ & $2.88^{d}$ & $3.10^{\mathrm{c}}$ & $3.24^{b}$ & $3.38^{\mathrm{a}}$ & \\
\hline \multicolumn{6}{|c|}{ \% Acidity } \\
\hline T1 & 0.99 & 1.30 & 1.33 & 1.40 & $1.26^{\mathrm{A}}$ \\
\hline $\mathbf{T} 2$ & 0.85 & 0.94 & 1.00 & 1.20 & $0.99^{\mathrm{B}}$ \\
\hline T3 & 0.80 & 0.87 & 0.92 & 0.96 & $0.89^{\mathrm{C}}$ \\
\hline T4 & 0.78 & 0.84 & 0.88 & 0.93 & $0.86^{\mathrm{D}}$ \\
\hline T5 & 0.75 & 0.81 & 0.86 & 0.89 & $0.83^{\mathrm{E}}$ \\
\hline Mean $^{* *}$ & $0.83^{d}$ & $0.95^{\mathrm{c}}$ & $0.99^{b}$ & $1.08^{a}$ & \\
\hline \multicolumn{6}{|c|}{ pH } \\
\hline T1 & 5.36 & 5.33 & 5.33 & 5.30 & $5.33^{\mathrm{D}}$ \\
\hline $\mathbf{T} 2$ & 5.50 & 5.41 & 5.36 & 5.35 & $5.41^{\mathrm{C}}$ \\
\hline T3 & 5.56 & 5.45 & 5.41 & 5.38 & $5.45^{\mathrm{BC}}$ \\
\hline T4 & 5.59 & 5.52 & 5.45 & 5.41 & $5.49^{\mathrm{AB}}$ \\
\hline T5 & 5.60 & 5.56 & 5.48 & 5.44 & $5.51^{\mathrm{A}}$ \\
\hline Mean $^{* * *}$ & $5.52^{\mathrm{a}}$ & $5.45^{b}$ & $5.41^{c}$ & $5.38^{c}$ & \\
\hline
\end{tabular}


Changes in fat content based on dry matter (F/DM) of different Kashkaval cheese treatments during the storage period are shown in Table (3). It can be seen from values given in Table (3) that with increasing the level of Transglutaminase, there was a significant $(\mathrm{P} \leq$ $0.05)$ increase in fat on dry matter (F/DM) content as compared with control low-fat Kashkaval cheese (T2). These results are in agreement with those reported by (El-Kholy, 2005; Ya-nan $\mathrm{Hu}$ et al., 2013). Transglutaminase can increase the gel strength of dairy products by catalyzing the covalent bond of $\mathcal{E}-(\gamma-$ glutamyl) lysine. So, a stronger rennet gel catalysed by TGase can prevent rennet curd from being smashed and fracturing and hence fat loss reduced (Bönisch et al., 2008). It was noticed that F/DM content of all cheese treatments increased significantly $(\mathrm{P} \leq 0.05)$ as storage period advanced.

Data illustrated in Table (3) showed that total nitrogen content of low fat Kashkaval cheese treatments significantly $(\mathrm{p}<0.05)$ higher than that of control full-fat cheese (T1) when fresh and throughout the ripening period. Adding Transglutaminase at all levels studied were increased significantly $\mathrm{TN}$ content $(\mathrm{p} \leq 0.05)$ as compared with control full-fat (T1) and control low-fat (T2). Same results were found by El-Kholy (2005), Metwally et al. (2018). There is a significant $(\mathrm{P}<0.05)$ differences among all treatments throughout the storage period. During the 45 days of storage, the TN content increased significantly $(\mathrm{p} \leq 0.05)$ among all treatments. This increase might be due to loss of moisture content during the storage period. These results in agreement with Abd El-Gawad et al. (2007) for low fat gouda like cheese; Ya-nan $\mathrm{Hu}$ et al. (2013) for low fat cheddar cheese.

Salt on moisture $(\mathrm{S} / \mathrm{M})$ content in the low fat treatments are higher $(\mathrm{P} \leq 0.05)$ than the full fat control cheese (T1). Also, with increasing the level of transglutaminase treated milk, there was a significant $(\mathrm{p}<0.05)$ increase in $\mathrm{S} / \mathrm{M}$ content. Meanwhile, salt on moisture(S/M) content increased during the ripening period as a result of the decrease in moisture content. These results are in agreement with those reported by Santa and Srbinovska (2014), El- Aidie et al. (2019).

From Table (3), it was noticed that the acidity of low fat cheese treatments was lower than control full fat cheese $(\mathrm{T} 1)$. There was a significant $(\mathrm{p} \leq 0.05)$ decrease in acidity $\%$ and a significant $(\mathrm{p} \leq 0.05)$ increase in $\mathrm{pH}$ values with the increase of Transglutaminase levels added. Similar results also observed by El-Kholy (2005) for low fat Tallaga cheese. As shown in Table (3), there was a continuous increase in acidity and a decrease in $\mathrm{pH}$ values during the storage period, this mainly due to the development of lactic acids by lactose fermentation by starter culture bacteria. These results in agreement with El-Kholy (2005), Santa and Srbinovska (2014) for Galichki Kashkaval and Ibrahim et al. (2017) for UFwhite soft cheese.

Water soluble nitrogen content of cheese was considered an indication of proteolysis during ripening.
Data given in Table (4) illustrated that Percentage of water soluble nitrogen of full fat control cheese (T1) was lower among all treatments. These result in agreement with Romeih et al. (2002), Awad et al. (2005). Water soluble nitrogen (WSN \%) and water soluble nitrogen coefficient (WSN/TN \%) increased significantly $(\mathrm{p} \leq 0.05)$ as storage progressed. Similar results reported by Niro et al. (2014), Talevski et al. (2017). Adding Transglutaminase at all levels increased water soluble nitrogen content and water soluble nitrogen coefficient significantly $(\mathrm{p} \leq 0.05)$ as compared with control full-fat (T1) and low fat kashkaval cheese (T2). These results are in agreement with El-Kholy (2005), Ahmed et al. (2015). El- Aidie et al. (2019) stated that the higher $\mathrm{SN}$ in cheese made with fat replacer may be attributed to excessive protein breakdown occurring through the growth of cheese microflora and proteolytic enzyme activity that eventually associate with extra moisture retained by fat replacers. The moisture (which contains soluble chymosin) content of the cheese with decreasing fat content might have been expected to increase the amount of proteolysis (Rudan et al., 1999).

The colour intensity resulted from the reaction of water soluble extract of cheese with Cd-ninhydrine reagent was chosen as an indicator of the liberation of free amino acids as final product of proteolysis in cheese. Color development (A 507) in soluble water extracts of full and low fat cheeses during the storage period indicated that the concentration of free amino acid was related to the concentration of water soluble nitrogen and that the concentration of free amino acid increased during storage progressed. As it is expected, the low fat kashkaval cheese control (T2) had higher $(\mathrm{P} \leq 0.05)$ concentrations of FAA than full fat cheese control (T1). This may be due to the higher total nitrogen content in control (T2) than control (T1). ElKholy (1995), Khalil (2003) reported that concentration of amino acid increased significantly with decreasing fat content. Using Transglutaminase with different ratios increased (A 507) values significantly $(p \leq 0.05)$. This may be due to the higher moisture content that activate the degradation of protein. Same trends were found by El-Kholy (2005), Ahmed et al. (2015).

It is clear from Table (4) that total volatile fatty acids (TVFA) affected significantly $(\mathrm{P} \leq 0.05)$ with the fat content of the cheese, thus the control full-fat cheese (T1) had the highest $(\mathrm{P} \leq 0.05)$ value among all other treatments either when fresh or during the storage period. These results due to its higher fat ratio than the low-fat cheese treatments. Low fat kashkaval cheese containing TGase exhibited higher $(\mathrm{P} \leq 0.05)$ levels of total volatile fatty acid than control low-fat kashkaval cheese (T2). Also, TVFA content increased significantly $(\mathrm{P} \leq 0.05)$ with the increase of TGase ratios added. Ahmed et al. (2015) came to the same results in low-fat gouda like cheese. 
Table (4): Effect of using different percentages of Transglutaminase on water soluble nitrogen (WSN), water soluble nitrogen coefficient, free amino acids (expressed as A507) and total volatile fatty Acids (TVFA) of Kashkaval cheese during storage period at $10^{\circ} \mathrm{C}$ (Mean of three replicates)

\begin{tabular}{|c|c|c|c|c|c|}
\hline \multirow{3}{*}{ Treatments } & \multicolumn{4}{|c|}{ Storage period(days) } & \multirow{3}{*}{ Mean } \\
\hline & Fresh & 15 & 30 & 45 & \\
\hline & \multicolumn{4}{|c|}{ WSN\% } & \\
\hline T1 & 0.205 & 0.304 & 0.427 & 0.548 & $0.371^{\mathrm{E}}$ \\
\hline $\mathbf{T 2}$ & 0.246 & 0.334 & 0.465 & 0.601 & $0.412^{\mathrm{D}}$ \\
\hline T3 & 0.250 & 0.336 & 0.471 & 0.611 & $0.417^{\mathrm{C}}$ \\
\hline T4 & 0.253 & 0.340 & 0.476 & 0.619 & $0.422^{\mathrm{B}}$ \\
\hline T5 & 0.255 & 0.344 & 0.480 & 0.625 & $0.426^{\mathrm{A}}$ \\
\hline Mean & $0.242^{\mathrm{d}}$ & $0.332^{\mathrm{c}}$ & $0.464^{b}$ & $0.601^{\mathrm{a}}$ & \\
\hline \multicolumn{6}{|c|}{ WSN/TN\% } \\
\hline T1 & 4.988 & 7.153 & 9.930 & 12.569 & $8.66^{\mathrm{A}}$ \\
\hline $\mathbf{T 2}$ & 3.955 & 5.252 & 7.165 & 9.204 & $6.39^{\mathrm{E}}$ \\
\hline T3 & 3.987 & 5.266 & 7.224 & 9.299 & $6.44^{\mathrm{D}}$ \\
\hline $\mathbf{T 4}$ & 4.022 & 5.279 & 7.256 & 9.365 & $6.48^{\mathrm{C}}$ \\
\hline T5 & 4.028 & 5.308 & 7.284 & 9.398 & $6.50^{\mathrm{B}}$ \\
\hline Mean $^{* * * *}$ & $4.19^{d}$ & $5.65^{\mathrm{c}}$ & $7.77^{b}$ & $9.97^{\mathrm{a}}$ & \\
\hline \multicolumn{6}{|c|}{ FAA (A $507 \mathrm{~nm})^{*}$} \\
\hline T1 & 0.014 & 0.063 & 0.108 & 0.164 & $0.087^{\mathrm{E}}$ \\
\hline $\mathbf{T} 2$ & 0.029 & 0.081 & 0.210 & 0.258 & $0.145^{\mathrm{D}}$ \\
\hline T3 & 0.031 & 0.095 & 0.218 & 0.263 & $0.152^{\mathrm{C}}$ \\
\hline T4 & 0.033 & 0.096 & 0.222 & 0.266 & $0.154^{\mathrm{B}}$ \\
\hline T5 & 0.034 & 0.099 & 0.227 & 0.270 & $0.158^{\mathrm{A}}$ \\
\hline Mean & $0.028^{d}$ & $0.075^{\mathrm{c}}$ & $0.197^{b}$ & $0.244^{\mathrm{a}}$ & \\
\hline \multicolumn{6}{|c|}{ TVFA $^{* * *}$} \\
\hline T1 & 3.00 & 5.50 & 7.70 & 8.20 & $6.04^{\mathrm{A}}$ \\
\hline $\mathrm{T} 2$ & 1.20 & 2.00 & 3.10 & 3.50 & $2.45^{\mathrm{E}}$ \\
\hline T3 & 1.30 & 2.30 & 3.70 & 4.00 & $2.83^{\mathrm{D}}$ \\
\hline T4 & 1.50 & 2.60 & 4.00 & 4.50 & $3.15^{\mathrm{C}}$ \\
\hline T5 & 1.50 & 2.80 & 4.20 & 4.80 & $3.33^{\mathrm{B}}$ \\
\hline Mean"* & $1.70^{d}$ & $3.04^{\mathrm{c}}$ & $4.49^{b}$ & $5.00^{\mathrm{a}}$ & \\
\hline
\end{tabular}

See Table (2) for treatments designation

"FAA expressed as absorbance at $507 \mathrm{~nm} / 100 \mu 1$ of water soluble nitrogen.

**TVFA expressed as $\mathrm{ml} 0.1 \mathrm{~N} \mathrm{NaOH} / 100 \mathrm{~g}$ cheese

***a, b, c \& d and A, B, C, D \& E: means with the same letters among treatments and storage period respectively are not significantly different $(p>0.05)$

\section{Sensory evaluation:}

Data presented in Table (5), summarized the score recorded for flavour, body \& exture and appearance of low fat Kashkaval cheese as affected by using TGase as an enhancer of cheese quality. In addition to the chemical composition of the different treatments of cheese, organoleptic aspects were given full consideration. Since the aim was to produce a good quality of low fat Kashkaval cheese, then the criteria of scoring was a vital importance.

Full fat Kashkaval cheese (T1) gained the highest $(\mathrm{P} \leq 0.05)$ scoring points for flavour, body \& texture, appearance and overall acceptability either for fresh or through storage period. White (1993) reported that milk fat has a crucial role in cheese quality attributes since it can provide a range of functional roles in cheese such as: 1) flavour, as a flavour component carrier; 2) texture, e.g. meltability, 3) structure stability and, 4) appearance. Control full-fat Kashkaval cheese after 45 days of storage possessed a total score 95 points out of 100 while control low fat (T2) scored 79 points out of
100. The addition of Transglutaminase to low-fat kashkaval cheese highly $(\mathrm{P} \leq 0.05)$ improved the flavour, the body \& texture, appearance and overall acceptability. These results are in accordance with ElKholy (2005); Ahmed et al. (2015); Karzan et al., (2016); Ibrahim et al. (2017). When fat is partially removed, as in low fat cheese, casein plays a greater role in curd texture development. There is inadequate breakdown of casein and therefore, the cheese appears to have a relatively firm texture. It is well known that milk fat provides a range of functional properties in cheese, contributing to sensory, structure and texture attributes of the product. Fat breaks up to protein matrix and plays the role of lubricant to provide smoothness and softer texture. In low fat cheese due to the dominating role of milk proteins, the product becomes hard and rubbery (Abd El-Gawad et al., 2007). Ahmed et al. (2015) found that addition of TGase improved the sensory properties of the resultant cheese "especially the body and texture" as a result of increasing its waterholding capacity and the cross-linking bonds between 
protein molecules. Özrenk (2006) stated that the introduction of additional covalent cross-linking by TGase represents a promoting tool to improve the functional properties for casein-based dairy products. The increase in TGase ratios had a positive effect on sensory attributes of all cheese samples. These results consistent with El-Aidie et al. (2019) for low fat Edam cheese and Chatlia et al. (2019) for low fat mozzarella cheese.

In general, for all cheeses total score points were higher $(\mathrm{P} \leq 0.05)$ at 45 days old cheeses as compared with fresh cheeses; this is well known that degradation of casein improve both texture and flavour. It was noticed that treatment $5(0.7 \mathrm{~g}$ TGase $/ \mathrm{L})$ gained the highest $(\mathrm{P} \leq 0.05)$ score for all sensory properties among all low fat Kashkaval cheese treatments when fresh and throughout ripening period.

The results obtained in this study indicate that using Transglutaminase improved low fat Kashkaval cheese yield, chemical composition and sensory properties when fresh and along storage period. A linear relationship was found between the concentration of TGase used and the improvement of cheese sensory attributes. The addition of Transglutaminase to low-fat kashkaval cheese highly improved the flavour, the body $\&$ texture, appearance and overall acceptability. Results concluded that low fat Kashkaval cheese can be successfully made from milk treated with $0.7 \mathrm{~g}$ TGase/L in order to obtain cheese of improved flavour, acceptable texture and good body.

Table (5): Effect of using different percentages of Transglutaminase on the Organoleptic properties of Kashkaval cheese during ripening periods at $10^{\circ} \mathrm{C}$ (Mean of three replicates)

\begin{tabular}{|c|c|c|c|c|c|}
\hline \multirow{3}{*}{ Treatment } & \multicolumn{4}{|c|}{ Storage period (days) } & \multirow{3}{*}{ Mean } \\
\hline & Fresh & 15 & 30 & 45 & \\
\hline & \multicolumn{4}{|c|}{ Flavour (50 points) } & \\
\hline T1 & 30 & 35 & 45 & 48 & $39.50^{\mathrm{A}}$ \\
\hline $\mathbf{T 2}$ & 25 & 27 & 33 & 40 & $31.25^{\mathrm{E}}$ \\
\hline T3 & 26 & 30 & 40 & 44 & $34.83^{\mathrm{D}}$ \\
\hline T4 & 26 & 30 & 42 & 45 & $35.75^{\mathrm{C}}$ \\
\hline T5 & 26 & 32 & 43 & 45 & $36.50^{\mathrm{B}}$ \\
\hline Mean & $26.6^{d}$ & $30.8^{\mathrm{c}}$ & $40.5^{b}$ & $44.4^{\mathrm{a}}$ & \\
\hline \multicolumn{6}{|c|}{ Body \& Texture (40 points) } \\
\hline T1 & 25 & 30 & 35 & 38 & $32.00^{\mathrm{A}}$ \\
\hline $\mathbf{T} 2$ & 17 & 20 & 28 & 32 & $24.25^{\mathrm{E}}$ \\
\hline T3 & 19 & 23 & 30 & 34 & $26.50^{\mathrm{D}}$ \\
\hline T4 & 20 & 25 & 32 & 36 & $28.25^{\mathrm{C}}$ \\
\hline T5 & 22 & 25 & 33 & 36 & $29.00^{\mathrm{B}}$ \\
\hline Mean & $20.6^{d}$ & $24.6^{c}$ & $31.6^{\mathrm{b}}$ & $35.2^{\mathrm{a}}$ & \\
\hline \multicolumn{6}{|c|}{ Appearance and colour (10 points) } \\
\hline T1 & 8 & 8 & 9 & 9 & $8.50^{\mathrm{A}}$ \\
\hline $\mathbf{T} 2$ & 6 & 7 & 7 & 7 & $6.75^{\mathrm{D}}$ \\
\hline T3 & 7 & 7 & 8 & 8 & $7.50^{\mathrm{C}}$ \\
\hline T4 & 7 & 8 & 8 & 8 & $7.75^{\mathrm{B}}$ \\
\hline T5 & 7 & 8 & 8 & 8 & $7.75^{\mathrm{B}}$ \\
\hline Mean & $7.0^{\mathrm{c}}$ & $7.6^{b}$ & $8.0^{\mathrm{a}}$ & $8.0^{\mathrm{a}}$ & \\
\hline \multicolumn{6}{|c|}{ Overall acceptability (100 points) } \\
\hline T1 & 63 & 73 & 89 & 95 & $80.08^{\mathrm{A}}$ \\
\hline $\mathbf{T} 2$ & 48 & 54 & 68 & 79 & $62.25^{\mathrm{E}}$ \\
\hline T3 & 52 & 60 & 78 & 86 & $69.00^{\mathrm{D}}$ \\
\hline T4 & 53 & 63 & 82 & 89 & $71.75^{\mathrm{C}}$ \\
\hline T5 & 55 & 65 & 84 & 89 & $73.25^{\mathrm{B}}$ \\
\hline Mean & $54.20^{d}$ & $63.00^{c}$ & $80.26^{b}$ & $87.60^{a}$ & \\
\hline
\end{tabular}

See Table (2) for treatments designation

**a, b, c \& d and A, B, C, D \& E: means with the same letters among treatments and storage period respectively are not significantly different $(\mathrm{p}>0.05)$

\section{REFERENCES}

Ahmed, M. A., Amal M. M. M.M. El-Nimer, M. A. Mostafa and H. Omar (2015). Effect of fat replacer or transglutaminase on the quality of low-fat Gouda-like cheese. World Journal of Dairy \& Food Sciences, 10(2): 170-180.

Abd El-Gawad, Mona, A. M., Reda A. M. Sabek, Nagla A. Hegazi (2007). Quality and properties of low-fat buffaloe 's kashkaval cheese. International Journal of Dairy Science, 2(3): 244-251.

Alichanidis, E. and A. Polychroniadou (2008). Characteristics of major traditional regional cheese varieties of east mediterranean countries: A review. Dairy Science and Technology, 88(4-5): 495-510. 
Awad, S., A. N. Hassan and F. Halaweish (2005). Application of exopolysaccharide producing cultures in reduced-fat cheddar cheese: composition and proteolysis. Journal of Dairy Science, 88(12): 4195-4203.

AOAC (2007). Official methods of analysis $18^{\text {th }} \mathrm{ed}$., Association of Official Analysis Chemists Inc., USA

Bonisch, M. P., T. C. Heidebach and U. Kulozik (2008). Influence of transglutaminase protein cross-linking on the rennet coagulation time. Food Hydrocolloids, 22(2): 288-297.

Chatlia, M. K., N. Gandhib and P. Singha (2019). Quality of Low- fat Mozzarella cheese with Different Fat Replacers. Acta Alimentaria, 48(4): 441-448

Costat (1998). Users manual for Costat version 6.311. Cohort soft ware; Berkeley; CA.

El-Aidie, S. A. M., E. I. Ghita, S. M. El-Dieb and HE.M. El-Garhi (2019). Physicochemical, Microstructural and Sensory Impact of Fat Replacers on Low-fat Edam Cheese Manufactured from Buffalo's Milk. International Journal of Advancement in Life Sciences Research, 2(3): 11-21

El-Kholy, A. M. (1995). Intervarietal Comparative Study of Proteolysis in Cheese PhD. Thesis.

El-Kholy, A. M. (2005). Influence of Tansglutaminase (TGase) Enzyme on the Quality of Low Fat Tallaga Cheese. Journal of Agricultural Science, Mansoura University, 30(9): 54075418.

Folkertsma, B. and P. F. Fox (1990). Use of the Cdninhydrin reagent to assess proteolysis in cheese during ripening. Journal of Dairy Research, 59(2): 217-224.

Fox, P. F., T. P. Guinee, T. M. Cogan and P. L. H. McSweeney (2000). Cheese rheology and texture, In Fundamental of Cheese Science, Aspen Publications, USA, pp. 305-324.

Gauche, C., J. T. C. Vieira, P. J. Ogliari and M. T. Bordignon-Luiz (2008). Cross-linking of milk whey proteins by transglutaminase. Process Biochemistry, 43(7): 788- 794.

Han, X. Q. and J. E. Spradin (2000). Process for making cheese using transglutaminase and non-rennet protease. United States Patent, No. 6(093): 424.

Ibrahim, O., P. Glibowski, M. Nour, M El-Hofi, E. ElTanboly and N. Abd-Rabou (2017). Effect of rosemary transglutaminase on yoghurt fortified with whey protein isolate. Polish Journal of Food and Nutrition Sciences, 67(4): 265-274.

Karzan, T. M., H. S. Nawal and T. A. Ashna (2016). The effect of microbial transglutaminase enzyme on some physicochemical and sensory properties of goat's whey cheese. International Food Research Journal, 23(2): 688-693.

Khalil, R. A. M. (2003). Acceleration ripening of low fat Ras cheese Msc. Thesis, Suez Canal University.
Koca, N. and M. Metin (2004). Textural, melting and sensory properties of low fat fresh kashar cheese produced by using fat replacers. International Dairy Journal, 14(4): 365-373.

Kosikowski, F. V. (1982). Cheese and Fermented Milk Foods. $2^{\text {nd }}$ ed. F. V. Kolskowski Associates, Brooktonale, New York.

Ling, E. R. (1963). Text Book of Dairy Chemistry. Vol.2. Practical, 3 rd ed., Chapman and Hall limited, London.

Metwally, M. M. E., H. M. El-Zeini and E. F. Gazar (2018). Impact of Using Transglutaminase Enzyme in Manufacturing Low and High Fat Mozzarella Cheese. Journal of Food, Nutrition and Population Health, 2(1): 1-5.

Niro, S., A. Fratiani, P. Tremonte, E. Sorrentino, L. Tipaldi, G. Gianfranco Panfili and R. Coppola (2014). Innovative Caciocavallo cheeses made from a mixture of cow milk with ewe or goat milk. Journal of Dairy Science, 97(3): 1296-1304.

Özrenk, E. (2006). The use of transglutaminase in dairy products. International Journal Dairy Technology, 59(1): 1-7.

Pappas, C. P., E. Kondly, L. P. Voustsinas and H. Mallatou ( 1996 ). Effect of starter level, draining time and aging on the physicochemical, organoleptic and rheological properties of Feta cheese. International Journal Dairy Technology, 49(3): 73-78.

Romieh, E. A., A. Michaelidou, C. G. Biliaderis and G. K. Zerfiridis (2002). Low-Fat white-brine cheese made from bovine milk and two commercial fat mimetics. Chemical, Physical and Sensory attributes. International Dairy Journal, 12(6): 525-540.

Rudan, M. A., D. M. Barbano, J. J. Yun and P. S. Kindstedt (1999). Effect of fat reduction on chemical composition, proteolysis, functionality, and yield of Mozzarella cheese. Journal of Dairy Science, 82(4): 661-672.

Santa, D. and S. Srbinovska (2014). Traditional production and main characteristics of Galichki Kashkaval. Mljekarstvo, 64(2): 119-126.

Seguro, K., N. Nio and M. Motoki (1996). Some characteristics of a microbial protein crosslinking enzyme: Transglutaminase. in: Macro Molecular Interactions in Food Technol., edited by Parris, N; A. Kato; L. K. Creamer; J. Pearce, ACS Symposium Series 650, American Chemical Society Columbus, OH. pp. 271-280.

Simov, Zh. I. and G. Y. Ivanov (2005). Proteolytic activity of Lacctobacillus delbrueckii ssp. bulgaricus and Streptococcus thermophilus in frozen-stored kashkaval cheese. Journal of Industrial Microbiology \& Biotechnology, 32(10): 449-454.

Talevski, G., S. Srbinovska, D. Santa and N. Mateva (2017). Influence of packaging on Kashkaval quality. Mljekarstvo, 67(1): 25-32. 
Vujicic, I. F., M. Skrinjar and M. Vulic (1996). Role of protease from Penicillium roqueforti in the modification of cheese slurry and Trappist cheese ripening. Acta Alimintaria, 25(1): 1525.

White, C. H. (1993). Rapid methods for estimation and prediction of shelf-life of milk and dairy products. Journal of Dairy Science, 76(10): 3126-3132.

Ya-nan Hu; Ke-shan Ge, Lu Jiang, Hui-yuan Guo, Jie Luo, Fang Wang and Fa-zheng Ren. (2013). Effect of Transglutaminase on Yield, Compositional and Functional Properties of Low-fat Cheddar Cheese. Food Science and Technology Research, 19(3): 359-367.

\section{تحسين جودة جبن الكثكفال المنخفض الدهن باستخدام الترانس جلوتامينيز: أـ التأثير على ولى إنى

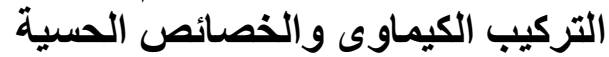
أميرة محمد الخولى، عاطف محمد أبو النور، رفيق عبد الرحمن خليل، محمد سميح الصفتى، صفاء محمود مقبل

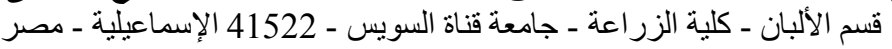

الهدف من الدر اسة هو معرفة تأثير استخدام تر انس جلوتامينز بنسب مختلفة على بعض الصفات التهن الفيزوكيمائية والحسية لجبن الكثكفال

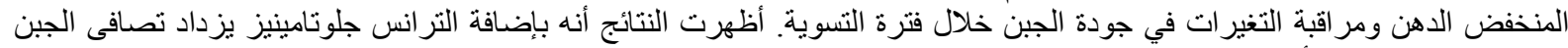

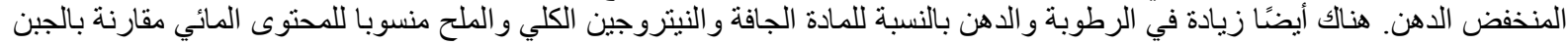

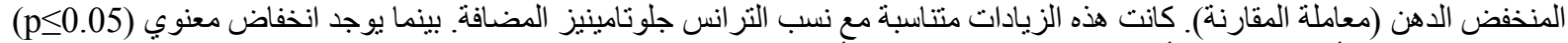

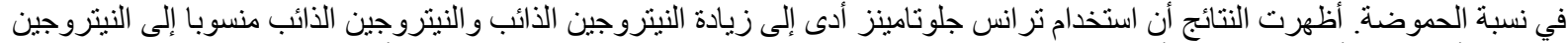

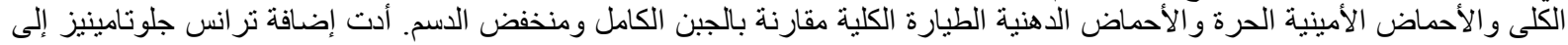

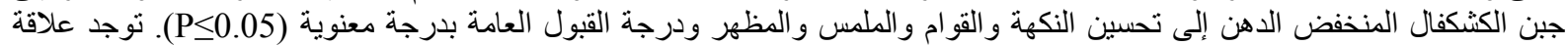

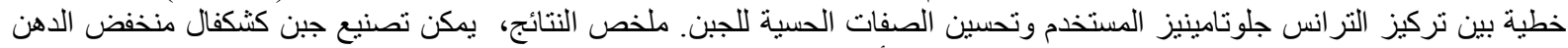

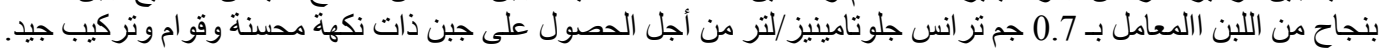

